European Journal of Training and Development Studies

Vol.9 No.1, pp.32-40, 2022

Print ISSN: 2057-5238(Print),

Online ISSN: 2057-5246(Online)

\title{
EFFECT OF GUIDED DISCOVERY METHOD ON SECONDARY SCHOOL STUDENTS' ACADEMIC PERFORMANCE IN BIOLOGY IN MAKURDI, BENUE STATE, NIGERIA
}

\author{
Msuur Tofi ${ }^{1}$; Emmanuel E. Achor ${ }^{2}$ and Victoria I. Eje ${ }^{3}$ \\ Department of Science and Mathematics Education, Benue State University Makurdi 1,2 \& 3
}

\begin{abstract}
Msuur Tofi; Emmanuel E. Achor and Victoria I. Eje (2022) Effect of Guided Discovery Method on Secondary School Students' Academic Performance in Biology in Makurdi, Benue State, Nigeria, European Journal of Training and Development Studies, Vol.9 No.1, pp.32-40
\end{abstract}

\begin{abstract}
This study investigated the effect of Guided Discovery method on Senior Secondary School students' academic performance in Biology in Makurdi, Benue State, Nigeria. Two research questions were raised and two null hypotheses were formulated. The study employed a quasi-experimental design. The population comprised of 8,670 Students in all the public Secondary Schools in Makurdi Metropolis. Two schools were randomly selected using simple random sampling technique from among the public Secondary Schools in Makurdi and a sample size of 47 Senior Secondary two (SS2) students were used for the study. The instrument used for data collection was Biology Academic Performance Test (BAPT). Biology Academic Performance Test (BAPT) was validated by 3 experts in science education. The $B A P T$ was pilot tested on intact class and a reliability coefficient of 0.79 was obtained using Kuder Richardson Formula-21 $\left(K-R_{21}\right)$. The research questions were answered using descriptive statistics of mean and standard deviation. The null hypotheses formulated were tested at 0.05 level of significance using inferential statistics of independent $t$-test. The findings showed that, there was a significant difference between the mean academic performance scores of students taught Biology using Guided Discovery method and those taught using Lecture method in favour of those students taught using Guided Discovery method. There was no significant difference between the mean academic performance scores of male and female students taught Biology using Guided Discovery method. It was recommended among others that; Biology teachers should use Guided Discovery method for teaching Biology at the secondary school level.
\end{abstract}

KEYWORDS: guided discovery method, science, biology, academic performance, gender

\section{INTRODUCTION}

Science is the foundation to our modern day scientific and technological world. Tofi, Usman and Lakpini (2021a) define science as a body of organized knowledge and a process of inquiry. Science plays very key roles in the growth and development of a nation in areas such as transportation, communications among others. It is because of the importance of science that the Federal Ministry of Education in its National Policy on Education (2014) emphasized the teaching of science subjects to its citizenry, some of the science subjects that were introduced are; Physics, Chemistry, Biology among others. 
Biology is one of the science subjects taught at the senior secondary school level. Ojekwu and Ogunleye (2020) describe Biology as the study of life. Biology is a core science subject which every science student is expected to get a credit at the O'level before proceeding to the University to study courses such as Medicine, Pharmacy, Nursing, and Veterinary among others. The importance of Biology cannot be over emphasized. In spite of the importance of Biology, there has been consistently poor academic performance by science students in Biology as revealed by Ndayambaje, Bikorimana and Nsanganwimana (2021). This was confirmed by West African Examination Council (WAEC) Chief Examiners report (2019). The poor academic performance of students in Biology has been a matter of concern to parents, government, teachers and researchers. Researchers have attributed the poor academic performance of students to some factors such as errors committed by students (Tofi et al 2021a) and also method of instructions employed by teachers as stated by Kayode (2020).

According to Kingdom-Aaron, Etokeren and Okwelle (2019) the method of instruction employed by most science teachers is the Lecture method. Lecture method as stated by Tofi, Usman and Lakpini (2021b), is the predominantly used teaching method in the teaching of science subjects, which is teacher-centered. Lecture method is a talk and chalk method. Lecture method helps in covering large content and it saves time. However, Kingdom-Aaron et al (2019) stated that lecture method is not efficient for improving student's academic performance as it does not give enough room for active participation of students which lead to their poor academic performance. Federal Ministry of Education in its National policy on education (2014) has discouraged the use of Lecture method and therefore recommended studentscentered method and activity based method such as Cooperative learning, Concept mapping, Simulation games and Guided Discovery Method.

Guided Discovery Method is defined by Dajal, Mohammed and Adamu (2019) as an approach to teaching in which students are guided by the teacher to find facts by themselves. Guided Discovery Method gives students the opportunity to investigate, use their discretion, contribute to knowledge, and get information individually or collectively to find a solution to a given task. It stimulates inquisitiveness and promotes students' enthusiasm to discover the answer to problems. Students tend to learn better and deeper when required to search, discover, and build essential information. Also Guided Discovery Method helps in fostering cooperation amongst learners. Guided Discovery method is a student-centered method that may enhance the academic performance of students with no regards to gender.

Gender according to Ozioko (2015) is a psychological term used in describing behaviours and attributes expected of individuals on the basis of being born as either male or female. There have been a lot of arguments on the effect of gender on academic performance of students in science. Salihu (2015) reported that, male students perform better than females in Ecology. On the contrary, Sukola, Abdumalik and Yunusa (2016) revealed that female students' achievement scores in Biology, were slightly better than those of their male colleagues. However, Onyejekwe, Uchendu and Nmom (2018) showed that gender has no significant effect on students' performance in Biology. From the aforementioned, there have been contradictory reports on the influence of gender on academic performance of students in Biology. Hence, this study investigated the effect of Guided Discovery method on senior secondary school Biology students' academic performance in Makurdi, Benue state. 


\section{Statement of the Problem}

The importance of Biology cannot be overemphasized. In spite of the importance of Biology, there has been an alarming rate of students' poor academic performance as reported by the WAEC chief examiners for the year $2015-2020$. This is of great concern to stakeholders including parents and researchers. Researchers such as Ojekwu et al (2020) and Ndayambaje et al (2021) have revealed that most teachers employ the lecture method in teaching science especially Biology which does not yield positive result on students' academic performance. This shows that students do not have an appropriate pedagogy while learning Biology. In search for a more appropriate strategy, the researchers therefore carried out this study on the effect of guided discovery method on senior secondary school biology students' academic performance in Makurdi, Benue State, Nigeria.

\section{Purpose of the Study}

The study therefore sought to:

1. Investigate the effect of Guided Discovery Method on mean academic performance scores of students taught Biology.

2. Determine the effect of Guided Discovery Method on mean academic performance scores of male and female students taught Biology.

\section{Research Questions}

The following research questions were answered in this study:

1. What is the difference between the mean academic performance scores of students taught Biology using Guided Discovery Method and those taught using Lecture method?

2. What is the difference between the mean academic performance scores of male and female students taught Biology using Guided Discovery Method?

\section{Null Hypotheses}

The following null hypotheses were formulated based on the Research Questions and were tested at $\mathrm{p} \leq 0.05$ level of Significance.

Ho1. There is no significant difference between the mean academic performance scores of students taught Biology using Guided Discovery Method and those taught using Lecture Method.

Ho2. There is no significant difference between the mean academic performance scores of male and female students taught Biology using Guided Discovery Method.

\section{RESEARCH METHOD}

The research design for this study is quasi-experimental design. Specifically, the study used non randomized pretest, posttest control group design. The population of this study comprised of all the 8,670 students (4,804 males and 3,866 females) in all the public Secondary Schools for 2020/2021 academic session in Makurdi Metropolis, Benue State (Benue State Teaching Service Board, 2021). Two schools were randomly selected from the population using simple random sampling technique of selection without replacement. Furthermore, simple random sampling technique of "Hat and Draw" was used to assign the two schools into experimental group and control group. The choice of this technique was to give every sampled school an equal chance of been selected. The sample size for the study was 47 Senior Secondary two (SS2) Biology students which comprised of 26 males and 21 females. The Experimental Group 
comprised of 15 male and 12 female students while the Control Group comprised of 11 male and 9 female students.

The instrument used for data collection for this study was Biology Academic Performance Test (BAPT). Biology Academic Performance Test is adapted from WAEC past questions from 2011-2020. BAPT is a 25 multiple choice questions with four options A, B, C and D. The Biology Academic Performance Test (BAPT) is based on the Senior Secondary two (SS2) syllabus covering the topic; Photosynthesis. It is comprised 2 sections: A and B. Section A contains the Bio - Information; examination number of students, sex, duration and instruction. Section B consisted of 25 items with four-options A, B, C and D. The Biology Academic Performance Test (BAPT) marking scheme. The time allocated is 30 minutes. Each correct answer attracts 1 mark while each wrong answer gives zero. The instrument (BAPT) was validated by 3 experts in science education. Kuder Richardson Formula-21 (K-R 21$)$ was used to determine the reliability of BAPT. The reliability coefficient obtained was 0.79 . The research questions were answered using descriptive statistics of mean and standard deviation. The null hypotheses formulated were tested at 0.05 level of significance using inferential statistics of independent t-test.

\section{RESULTS}

Table 1: Summary Analysis of t-Test on Students' Pretest Academic Performance Scores in Experimental and Control Groups

\begin{tabular}{llllllll}
\hline Groups & N & Mean & SD & df & t-cal & p-value & Remark \\
\hline $\begin{array}{l}\text { Experimental } \\
\text { Group }\end{array}$ & 27 & 10.15 & 2.52 & & & & \\
& & & & & & & \\
& & & & 45 & 1.19 & 0.24 & Not Significant \\
Control Group & 20 & 11.05 & 2.63 & & & & \\
& & & & & & & \\
\hline
\end{tabular}

Table 1 shows that there is no significant deference in students' pretest academic performance scores between experimental group and control group since p-value 0.24 is greater than 0.05 level of significance. Since the difference between the two groups in pretest is not statistically significant; the researchers proceeded to use t-test analysis on posttest result.

Research Question 1: What is the difference between the mean academic performance scores of students taught Biology using Guided Discovery Method and those taught using Lecture method?

Descriptive statistics of mean and standard deviation were used to answer this research question and summary of the result is presented in Table 2. 
Vol.9 No.1, pp.32-40, 2022

Print ISSN: 2057-5238(Print),

Online ISSN: 2057-5246(Online)

Table 2: Mean and Standard Deviation of Students' Academic Performance Scores in Experimental and Control Groups.

\begin{tabular}{lcccllc}
\hline Groups & $\begin{array}{l}\text { No. } \\
\text { Students }\end{array}$ & $\begin{array}{l}\text { of } \\
\text { Mean }\end{array}$ & $\begin{array}{l}\text { Sretest } \\
\text { Deviation }\end{array}$ & $\begin{array}{l}\text { Posttest } \\
\text { Mean }\end{array}$ & $\begin{array}{l}\text { Standard } \\
\text { Deviation }\end{array}$ & Mean Gain \\
\hline $\begin{array}{l}\text { Experimental } \\
\text { Group }\end{array}$ & 27 & 10.15 & 2.52 & 19.41 & 2.81 & 9.26 \\
Control Group & 20 & 11.05 & 2.63 & 14.25 & 2.57 & 3.20 \\
$\begin{array}{l}\text { Mean } \\
\text { Difference }\end{array}$ & & 0.9 & & 5.16 & & \\
Total & 47 & & & & & \\
\hline
\end{tabular}

The results in Table 2 show that the students taught Biology using Guided Discovery method have a pretest academic performance mean score of 10.15 with a standard deviation of 2.52 and posttest academic performance mean score of 19.41 with a standard deviation of 2.81 while those taught using Lecture method has a pretest academic performance mean score of 11.05 with a standard deviation of 2.63 and posttest score of 14.25 with a standard deviation of 2.57. The students in the experimental and control groups had academic performance mean gain of 9.26 and 3.20 respectively and with a mean gain difference of 6.06 in favour of the experimental group.

Research Question 2: What is the difference between the mean academic performance scores of male and female students taught Biology using Guided Discovery Method?

Descriptive statistics of mean and standard deviation were used to answer this research question and summary of the result is presented in Table 3.

Table 3: Mean and Standard Deviation of Male and Female Students' Academic Performance Scores in Experimental Group.

\begin{tabular}{lllllll}
\hline Groups & $\begin{array}{l}\text { No. } \\
\text { Students }\end{array}$ & $\begin{array}{l}\text { Pretest } \\
\text { Mean }\end{array}$ & $\begin{array}{l}\text { Standard } \\
\text { Deviation }\end{array}$ & $\begin{array}{l}\text { Posttest } \\
\text { Mean }\end{array}$ & $\begin{array}{l}\text { Standard } \\
\text { Deviation }\end{array}$ & $\begin{array}{l}\text { Mean } \\
\text { Gain }\end{array}$ \\
\hline Male & 15 & 10.73 & 2.69 & 19.73 & 2.58 & 9.00 \\
Female & 12 & 9.42 & 2.20 & 19.00 & 3.16 & 9.58 \\
$\begin{array}{l}\text { Mean } \\
\begin{array}{l}\text { Difference } \\
\text { Total }\end{array}\end{array}$ & $\mathbf{2 7}$ & 1.31 & & 0.73 & & 0.58 \\
\hline
\end{tabular}

The results in Table 3 show that male students taught Biology using Guided Discovery method have a pretest academic performance mean score of 10.73 with a standard deviation of 2.69 and posttest academic performance mean score of 19.73 with a standard deviation of 2.58 while female students taught Biology using Guided Discovery method has a pretest academic performance mean score of 9.42 with a standard deviation of 2.20 and posttest mean score of 
Print ISSN: 2057-5238(Print),

Online ISSN: 2057-5246(Online)

19.00 with a standard deviation of 3.16. Male and female students taught Biology using Guided Discovery method had academic performance mean gain of 9.00 and 9.58 respectively with a difference of 0.58 in favour of female students.

H01: There is no significant difference between the mean academic performance scores of students taught Biology using Guided Discovery method and those taught using Lecture method.

The independent t-test was used to test this hypothesis using post test scores. Being a quasiexperimental design study, the participants were not assumed to be homogeneous. Therefore ttest was used on pretest results.

The summary of the result is presented in Table 4.

Table 4: Analysis of Independent t-Test on Students' Academic Performance Scores in Experimental and Control Groups

\begin{tabular}{llllllll}
\hline Groups & N & Mean & SD & Df & t-Cal & p-value & Remark \\
\hline $\begin{array}{l}\text { Experimental } \\
\text { Group }\end{array}$ & 27 & 19.41 & 2.81 & & & & \\
& & & & 45 & 6.43 & 0.00 & $\mathrm{~S}$ \\
Control Group & 20 & 14.25 & 2.57 & & & & \\
\hline
\end{tabular}

$\mathrm{p} \leq 0.05$ Significant; $\mathrm{S}=$ Significant

Table 4 reveals that calculated t-value is 6.43 and $p$-value is 0.00 . Therefore, $p$-value of 0.00 is less than significant level of $\mathrm{p} \leq 0.05$. Based on this evidence, the null hypothesis was rejected. This shows that there is significant difference between the mean academic performance of students taught Biology using Guided Discovery method and those taught using Lecture method. This implies that Guided Discovery method was more effective than Lecture method in teaching and learning of Biology.

H02: There is no significant difference between the mean academic performance scores of male and female students taught Biology using Guided Discovery Method.

The independent t-test was used to test this hypothesis and the summary of the result is presented in Table 5. 
Vol.9 No.1, pp.32-40, 2022

Print ISSN: 2057-5238(Print),

Online ISSN: 2057-5246(Online)

Table 5: Analysis of Independent t-test of Male and Female Students' Academic Performance Scores in Experimental Group.

\begin{tabular}{lccccccc}
\hline $\begin{array}{l}\text { Experimental } \\
\text { Group }\end{array}$ & N & Mean & SD & Df & t-Cal & p-value & Remark \\
\hline Male & 15 & 19.73 & 2.58 & & & & \\
& & & & 25 & 0.67 & 0.512 & NS \\
Female & 12 & 19.00 & 3.16 & & & & \\
& & & & & & & \\
\hline
\end{tabular}

$\mathrm{P} \leq 0.05$ Significant; NS $=$ Not Significant

Table 5 shows the summary of the result of test of hypothesis two. From the table, the calculated t-value is 0.67 and $p$-value is 0.512 . Therefore, $\mathrm{p}$-value of 0.51 is greater than significant level of $\mathrm{p} \leq 0.05$. Based on this evidence, the null hypothesis was not rejected. This shows that there is no significant difference between the mean academic performance scores of male and female students taught Biology using Guided Discovery method.

\section{DISCUSSION OF FINDINGS}

The finding of this study shows that there was a significant difference between the mean academic performance scores of students taught Biology using Guided Discovery method and those taught using Lecture method in favour of the students taught using Guided Discovery method. This finding is in support of the findings of Dajal et al (2019) and Salihu (2015) who all found that students taught Biology using Guided Discovery method (experimental group) performed better than those students taught using Lecture method (Control group). Similarly, the findings of Ugwoke, Olulowo and Adedayo (2020) and Alabi and Lasisi, (2015) revealed that students in the experimental groups who were taught using Guided Discovery method achieved higher than their counterparts in the control group who were taught using Lecture method. The reason for the difference in academic performance is that Guided Discovery method is activity oriented teaching method that encourages active participation of students in class room activities and as well maximize comprehension of subject matter. It means that the method can be used to teach students since it reduces the problem of poor academic performance in Biology.

This study also revealed that there was no significant difference between the mean academic performance scores of male and female students taught Biology using Guided Discovery method. This result agrees with the findings of Dajal et al (2020) who revealed that there was no significant difference between male and female students' achievement taught using Guided Discovery method. However, the finding disagrees with the findings of Salihu (2015) who revealed that male students performed better than their female counterparts when taught using Guided Discovery method. 


\section{CONCLUSIONS}

The following conclusions were drawn from the findings of the study: Guided Discovery method was found to be an effective method in enhancing the academic performance of senior secondary school students in Biology. Guided Discovery method is an effective method that improved academic performance of senior secondary school students than those taught using Lecture method. Guided Discovery Method is gender friendly as it enhanced performance of both male and female students.

\section{Recommendations}

The following recommendations were made based on the findings of this study;

1. Biology teachers should use Guided Discovery method for teaching Biology at the secondary schools.

2. Guided Discovery method should be used to teach both male and female students as it is gender friendly.

\section{REFERENCES}

Alabi, T. O. \& Lasisi, N. (2015). Effects of guided discovery and problem solving on achievement of secondary school students' in volumetric analysis in Niger State. Journal of Science, Technology \& Education, 3(4), 75-87.

Dajal, R. G., Mohammed, \& Adamu, U. (2019). Effects of guided discovery method on students' attitude to, and achievement in Biology in senior secondary schools, Bauchi State. International Journal of Research and Scientific Innovation, 6(7), 105-110.

Federal Republic of Nigeria (2014). National policy on education. Lagos: Heinemann Educational books Ltd.

Kayode, F. O. (2020). Effect of peer tutoring on students' achievement in Biology in secondary schools in Ekiti State, Nigeria. International Journal of Education and Research, 7(1), 4047.

Kingdom-Aaron, G. I., Etokeren, I. S. \& Okwelle, P. C. (2019). Effect of cooperative learning strategy on Biology students' academic performance in senior secondary school in Rivers State. Journal of Scientific Research and Reports, 23(6): 1-11.

Ndayambaje, J. B., Bikorimana, E. \& Nsanganwimana, F. (2021). Factors contributing to the students' poor performance in Biology subject: A case study of ordinary level in rural secondary schools of Rwamagana district. GSC Biological and Pharmaceutical Sciences, 15(3), 249-261.

Ojekwu, I. N. \& Ogunleye, B. O. (2020). Effects of jigsaw learning strategy on science students' performance and interest in Biology in selected schools in Rivers State, Nigeria. Sapientia Foundation Journal of Education, Sciences and Gender Studies, 2(3), 325-334.

Onyejekwe, C. A., Uchendu, C. G. \& Nmom, T. (2018). Effect of concept mapping on students' performance in Genetics, in selected public schools in Obio/Akpor. International Journal of Education and Evaluation, 4(1), 54-60.

Ozioko, C. C. (2015). Effect of guided discovery method on academic achievement and interest of senior secondary school students in foods and nutrition in Nsukka education zone of Enugu State. Unpublished M.Ed Thesis. Nsukka: University of Nigeria, Nsukka. 
European Journal of Training and Development Studies

Vol.9 No.1, pp.32-40, 2022

Print ISSN: 2057-5238(Print),

Online ISSN: 2057-5246(Online)

Salihu, Z. (2015). Effects of guided discovery approach on students' academic performance in Ecology in senior secondary schools in Sokoto State, Nigeria. Unpublished M.Ed Thesis. Sokoto: Usmanu Danfodiyo University, Sokoto.

Sukola, I. T., Abdumalik, S., \& Yunusa, M. M. (2016). Comparative analysis of gender performances in Biology, Chemistry and Physics among pre-degree students of Federal University, Dutsinma. International Journal of Educational Benchmark, 5(1), 108-118.

Tofi, M., Usman, A. I., \& Lakpini, M. A. (2021a). Identification of common errors by basic eight students in Basic Science in Makurdi, Benue State, Nigeria. Journal of International Centre for Science and Education Research, 5(1), 112-119.

Tofi M., Usman, A. I. \& Lakpini, M. A. (2021b). Effect of jigsaw 1 jigsaw 1 cooperativelearning strategy on academic performance in basic science among students in Makurdi, Benue State, Nigeria. British Journal of Education, 9(10), 32-42.

Ugwoke, E. O., Olulowo, T. G., \& Adedayo, I. O. (2020). Using guided discovery to improve students' retention and academic attitudes to Financial Accounting concepts. Education Research International, 1-9.

Yerizon, A. P. \& Subhan, M. (2019). Mathematics learning instructional development based on discovery learning for students with intrapersonal and interpersonal intelligence (preliminary research stage), International Electronic Journal of Mathematics Education, 13(3), 97-101. 